\title{
Cultural Memory of Migrants of the Krasnoyarsk Territory (Krai) and Ethnic Self-Identification Processes
}

\author{
Yuliya N. Avdeeva* \\ Siberian Federal University \\ 79 Svobodny, Krasnoyarsk, 660041, Russia
}

Received 05.05.2018, received in revised form 27.05.2018, accepted 04.06.2018

The subject of the present research is cultural memory of migrants in the Krasnoyarsk Territory (Krai). Labour migration in the Krasnoyarsk Territory is a social, economic and cultural process. Migrants constitute a considerable share in the population of the Krasnoyarsk Territory.

Ethnic identity processes experienced by migrants are an up-to-date subject in cultural research. Ethnic identification of migrants in the Krasnoyarsk Territory is determined by their cultural memory. The essence of this memory is the basis for understanding the processes related to the governmental cultural and migration policy. Labour migration makes a tangible influence on social and cultural environment of the region.

The main method of the present research is a focused group interview. The method was applied to the migrants belonging to Armenian, Azerbaijani and other ethnic cultural groups resident in the Krasnoyarsk Territory.

The academic novelty of the research is connected to the application of the focused group interview method to the research of cultural memory of the migrants living in the Krasnoyarsk Territory. Younger migrants associate themselves with Russian culture. Social heritage of these young people is different from the ethnic one: despite ethnic assimilation (language, everyday communication culture in the foreign environment), ethnocultural consolidation is still out of question.

Keywords: cultural memory, ethnicity, ethnic identity, ethnic self-identification, ethnocultural groups, ethnos, migration, migration processes, focus groups, cultural research.

DOI: 10.17516/1997-1370-0277.

Research area: culturology.

\section{Introduction. Background review}

The present research is dedicated to the study of cultural memory of the migrants, of the way the cultural memory influences the processes of adaptation, integration and self-identification of migrants. Contemporary humanities offer a wide range of methodological approaches (axiological, structuralist, functional, hermeneutic, generic, cross-cultural, linguistic and culturological etc.), as well as qualitative and quantitative methods, such as observation, description, field research, experiment, content analysis, narrative analysis, grounded theory, focus group etc. Each of them may be efficiently applied to the research of

(C) Siberian Federal University. All rights reserved

* Corresponding author E-mail address: yulia-avdeeva2406@mail.ru 
cultural memory of various ethnic groups of migrants. Theoretical methods are described in the first part of the research; the second chapter is dedicated to practical interdisciplinary methods. The ethnocultural research of the ethnic groups of migrants is made with the focused group interview method due to the opportunity of direct communication with people from various ethnic groups in order to study their attitude to their own ethnic culture and cultures of other groups, to see and to describe the development dynamics of this or that ethnic group.

Historically, the focus group method (shorted from "focused group interview") is a qualitative method of sociological research. For the first time it was used by sociologists R.K. Merton and P.F. Lazarsfeld in 1944, and the first theoretical description was carried out and presented by R.K. Merton, J.P. Kendall, M. Fiske in "The Focused Interview" in the year 1946. Today, focus group method is widely used in sociology, culturology, psychology, political science, economics etc. Russian tradition of the method is still developing, completely relied on Western experience. The most recognized advocates of the method in our country are the authors of specialized teaching aids: S.A. Belanovskiy, N.N. Bogomolova, O.T. Mel'nikova and T.V. Folomeeva.

The focus group study is a thorough interview of target audience representatives. During the interview, the researchers collect individual opinions of the respondents on the research object (goods, services, activities, products etc.). In other words, focus group method is a group discussion: free of ideological mindsets, respondents feel comfortable and easy in their replies, providing researchers with relevant information. This method has the following distinctive features:

- focused interview means active social interaction;

- the purpose is to collect the most truthful data, derived in the communication process;
- information obtained from the focused interview is essential and extremely valuable for research.

At first, the method seems to be nothing but a record of opinions expressed by the group, brought together to discuss a certain topic. However, the focused interview method has a series of advantages, as due to some specific techniques, it enables the researcher to:

- formulate the general view on this or that problem;

- outline both positive and negative influence factors;

- carry out an easy and free discussion, moving from general questions to specific and vice versa;

- consider all aspects of the topics separately and collectively;

- ensure a conversation with the moderator and between the guests;

- obtain information beyond existing hypotheses, expanding the existing idea of the studied subjects, as well as a dramatic change of attitude to it;

- come up with hypotheses, formulate new ideas and approaches to the studied topic.

Speaking about the focused interview procedure, it should be noted that, just like any other sociological research, it includes, first of all, development of a programme that sets and justifies the problem, formulates the objective, tasks, the object and the subject of the research, number and composition of focus groups, mechanism of collecting and processing the information. As a rule, no hypotheses of problem interpretation are suggested at this stage. Secondly, a team of a moderator (a person with experience in the studied topic) and assistants is formed. The assistants are responsible of audio and video recording, registering the characteristics of the respondents' cues (emotionality, gestures, nonverbal characteristics) and ensuring discipline. 
Thirdly, before the test or the interview, groups of respondents are formed. Focus group participants may be recruited randomly or with the "snowball" principle (one participant names a candidate who matches the established criteria; that candidate names another etc.). It is important to remark that it is not recommended to use established groups consisting of people who know each other, participants of previous focus groups and specialists in the area, as it may influence the course of discussion. Fourthly, there is an organized plan (guide), consisting of a welcome speech, announcement of the main rules, formulation of questions divided into conceptual parts. The plan includes timing and duration of breaks.

Such research mechanism creates advantageous conditions for the respondents to express spontaneous emotions and sincere opinions. In a group discussion, a real situation is modelled and opinions are expressed; people speak consciously, aware of the responsibility of their views. The distinctive features of qualitative research are dynamicity and variability, which can be used to the maximum: the activeness and personal involvement into the topic provoke spontaneous replies, unplanned (not previously played) by the respondents, since the presence of other people often encourages the conversation. The proceedings of the discussion, recorded in a report, are easy to understand for the customer of the research, while quantitative data consisting of diagrams and graphs are not always equally satisfying. The focused group interview method brings quick results, remaining affordable at the same time.

The advocates of modern qualitative research methods claim that it is worthwhile to forget traditional formal methods in favour of the communicative methods operating live conversation and language, for "this is the return to the internal structure of Russian language, especially to the filters, since Russian language is absolutely unique" (round table "The Values We Have", July, 2005. Byzov, L., L’vov, N., Igrunov, V. et al.); it reveals the values and stereotypes of people. It proves the relevance of such open research method as a focused group discussion.

Moreover, the need for qualitative sociological methods in a study of ethnic migration processes is explained by the fact that they are not only substantial; they integrate methods, general research approaches and achievements in the spheres of sociology, history, ethnography, social and cultural anthropology, which means that the results they bring are less biased, more comprehensive and justified. Such methods are a way of a thorough study, interpretation and modelling of relationships between different peoples, of describing the specificity of ethnical world outlooks and self-identification of ethnocultural groups within them.

In his book "The Focus Group Method", S.A. Belanovsky presents a comprehensive study of the focused group interview method. He tells the method history, explains the reason for changes in methodological priorities in qualitative methods of academic sociology, considers theoretical aspects of the group interview method and focus group in the context of empirical sociological methods, describes the general principles for group formation, focused interview organization issues etc. The group gathered for an interview is a model of society; consequently, the conclusions drawn from such research can be extrapolated on wider spheres of life. Group interview provides an opportunity for self-observation and self-analysis, while many processes people experience in their everyday life are subconscious or semi-conscious, habitual or automatic, so, "even a man organized in his thoughts has a limited capacity for interpreting his own motivations and mindsets". 
Fundamental institutions of cultural, sociological and ethnographic studies organize seminars and conferences on the integration of archaeological and ethnographic research, raising questions of studying ethnicities, ethnic communities and processes, solving contemporary problems with integrated qualitative methods.

In her article "Focus Group Method: Problems of Preparation and Analysis", considering the potential of using the method beyond the sphere of marketing, along with various theories of determining method specifics and relying on the approaches of R. Merton, A.E. Goldman, and R.A. Krueger, E.V. Dmitrieva suggests the following definition: "Focus group is a qualitative method of collecting sociological information in homogenous (in the features relevant for the research) groups with a focus of discussion, with the help of a moderator, based on the group dynamics principle". She explains the rationality of using the method in sociology, pointing out group dynamics, i.e. continuous process of interaction, as the main distinctive feature of a focus group, opening the potential of revealing up-to-date problems (mutual influence of opinions, fear of public expression, spontaneous or intentionally created conflicts). Another distinctive feature of the method is the fact that participants are encouraged to behave naturally (in comparison to a small group), as the purpose of discussion is to collect a number of opinions on this or that subject, not to make a collective solution or reach a consensus". The collective information is checked for representativeness; to achieve it, recommendations on group formation shall be observed. After the focus group session, the collected materials are analysed as a combination of verbal and non-verbal data. The most effective analysis methods are: linguistic analysis (conversation analysis), discourse analysis and content analysis. In the process of study, the researcher finds connections between the text and the phenomena underlying the statements (social control, gender relations etc.). It is remarked that a text is not just a combination of matched words; it is a variation of an event or a phenomenon, presented by an individual, and has a doubtless right to exist. The focus group organizing team shall be aware of the verbal and non-verbal symbols generation process, be able to find the special context that is lost when quantitative research methods are used. The author finds problems in relying exclusively on focus group results; however, this method is irreplaceable in sociology, being the only one able to prove the authenticity of the provided answers and to present a variety of views over one and the same issue.

I.V. Chekhovsky studies the focus group method in the context of methodology of empirical sociology, where it is capable of revealing latent social problems (interethnic relations, attitude to the poor, disabled, attitude of mothers to children, teenage problems etc.), as well as achieving the objective of large-scale research projects. Therefore, the method may be used not only as a basic, but also as an auxiliary one, complementing the selected core method.

E.A. Briantseva studies the specificity of forming focus groups and applying the method in sociological research, using focus group method as a tool for the analysis of modern Russian consumer socialization, for sociological research of values of mothers of newborns in the medical institution environment.

For the past decades, Russian and foreign researchers have accumulated a lot of theoretical findings and relevant experience of using the qualitative method in humanities. Integrated with other methods, focus group method is used for the study of migration issues, interethnic and interconfessional relations, ethnic and gender identity, multiculturalism, ethnic policy etc. 
Moscow Centre of Gender Research uses the method for gender identity studies. Gender identity is regarded as a basis for social identity, which characterizes an individual from the point of view of their being a man or a woman. In this context, the way the individual identifies his or herself is extremely important. Focus group method opens an opportunity to create the conditions of a close and at the same time dynamic interaction with the respondents, to carry out thorough and deep discussions, to reflect on the most relevant gender issues.

Since 2006, the Eurasia Heritage Foundation has been a participant of a comprehensive study of processes developing within the community of Russian fellow citizens in four countries of Europe (Germany, Latvia, Romania, Estonia). In 2008, the project "Impossible Diaspora. Russians and Russian Speakers in the EU Countries", intended to study the status of Russian citizens in European countries, was organized. The research was based on empiric methods, including focus group and expert survey methods. The reference groups consisted of the Russian speakers involved in the development, implementation and media representation of ethnic policy in the countries of their residence, support and development of Russian language, culture and education, diaspora advocacy etc. The mass survey was carried out among the people identifying themselves as the bearers of Russian language, culture and traditions, regardless of their citizenship or ethnicity. The conversation monitoring determined the structure of Russian diaspora, its ethnic composition in each country, its history and characteristics, describing the involvedness of the diaspora into social life in the country of residence. One of such signals is the share of diaspora members, being citizens of the corresponding states. In this context, all the four countries are different. Therefore, as the research demonstrated, citizenship does not play a critical role for certain categories of Russian speaking expats. However, language command turned to be the key feature for the identification of a Russian diaspora member and his/her specificity; at that, the focus groups revealed that command of both the titular ethnic group language and Russian are relevant. The research stated, that the most integrated Russian diaspora, preserving its own originality, is the diaspora in Romania, however, its representatives occupy a periphery position in the "Russian world". Russian diasporas in Germany, Estonia and Latvia do not exist, due to their diversity in both ethnical origin and the attitude to Russia. The collected data expand the sphere of research, provides a basis for general ethnos studies, raise the problem of defining ethnos borders within the society, the group forming mechanism etc.

O.V. Shchedrina is involved in researching the issues of migration, multiculturalism policy, discussion of the potential of the governmental policy studied in the research projects monitored by L.M. Drobizheva. On the basis of the focus group method, it becomes possible to create a multicultural integration model and reproduce multicultural conditions. O.V. Shchedrina provides a detailed description of the problem and the methodology of her research: "The fact of acceptance of the multicultural integration model by the state means its openness to the migrants presenting alien ethnicities and responsibility for creating conditions for proper integration. In the meanwhile, due to the ethnic diversity of Russian population, the government is obliged to take care not only of migrants, but also of the peoples who have been living in the territory of the country for a long time". Russia has set the task to ensure integration of culturally and ethnically different nations, to develop popular image of Russian identity, to unite the ethnically diverse population around common objectives and values. The stable 
growth of ethnophobia proves the acuteness of these tasks in modern Russia.

Upon the Order of the Government of Moscow, the Ethnic Sociology Centre of the Institute of Sociology of the Russian Academy of Sciences carried out a research of interethnic relations within the city. To reveal the common opinion of the ethnic migrants, the focus group method was used, bringing $4^{\text {th }}$ and $5^{\text {th }}$ year students of Moscow colleges into the research. The group was expected to provide proactive information, since several years after their opinion will be the one to determine the interethnic relations in their local environment. The materials collected at focus group sessions demonstrated exaggeration of the number of ethnic migrants in Moscow, which means the existence of migrant phobia (the respondents estimated the share of migrants in Moscow population as 40-60 \%). Moreover, as representatives of the host city, the students demonstrated a negative attitude to both ethnic migrants and migrants as a whole. The ideas of providing migrants with governmental support at the stage of adaptation, including the establishment of adaptation centres and other social programmes intended to assist ethnic migrants, were not supported by the students.

Analysing the existing solutions, O.V. Shchedrina comes up with a number of ways to solve this problem. Due to the current situation in Russia, no integration model can be perceived in an unconditionally positive way: multiculturalism is criticized by the majority, and assimilation does not satisfy the situation of ethnic minorities, i.e. the peoples originally resident in the territory of Russia. However, there is another way, common for countries that consider official acceptance of multiculturalism impossible for a number of reasons. In the meanwhile, it is absolutely necessary to use the integration potential to preserve the state as it is. Such a compromise model may be multiculturalism-based activity of the state bodies, carried out in a close collaboration with the polyethnic population. This activity spreads the multicultural ideologemes around the whole administration system, up to local subdivision of the governmental institutions, expanding and establishing such practices at the local level. Moreover, such model of activity helps the state operate the specificity and the condition of interethnic relationships in the regions in a more efficient way, at the same time keeping practical application of multicultural policy under control. Using the governmental institution acting on the multicultural principle as a channel of it influence, Russian authorities may solve the issue of advocacy of Russian-speakers resident in certain Russian republics, who, according to multiple ethnosociological surveys, identify themselves as an ethnic minority. This acceptance of the "right to cultural difference" proves the readiness of the state to organize a tolerant and liberal integration process for the benefit of all citizens of the country.

Therefore, modern scientific literature leads us to the conclusion, that within the last 20 years the popularity of the focus group method in humanities is rapidly growing. It is explained by the fact that an organized group discussion collects deep and individualized material, the attitudes to certain phenomena and things an individual may be unaware of in his or her daily life, reveals cause-effect relations in the social and psychological phenomena. Unlike individual surveys, carried out with unified structured questionnaires, focus group is a method of a deep group interview, which gets beyond the "superficial" information and finds underlying attitudes or opinions on this or that problem. A doubtless advantage of the method is the volume of information and a variety of interpretation tools. Moreover, the focus group method is capable of solving a great range of tasks, since the respondent 
group represents a real-life society model. This is the reason why this method is so widely used in ethnocultural research (ethnography, studies of interethnic and interconfessional relations, migration processes etc.).

\section{Applying focus group method}

to the analysis of the cultural memory of ethnic migrant groups and its influence on the processes of integration, adaptation and self-identification

\section{Migrants of the Krasnoyarsk Territory}

(Krai) today

Just like other regions of the Russian Federation, the Krasnoyarsk Territory (Krai) is an interethnic and international environment with a great cultural and linguistic variety of nations. Today, there are 159 ethnocultural groups resident in the region. The population of the Krasnoyarsk Territory, located in the centre of Russia, remote from the state borders, is extremely mobile. It should be also noted, that though exchange with other entities of the Russian Federation result in the population outflow (statistic data proves that within the period of 2003-2015 the Krasnoyarsk Territory (Krai) lost 48606 people as a result of such migration flow), international migration increases the population number (Table 1). Migrants disperse around the whole territory of the region, predominantly in towns: almost 2.7 times more people than in rural areas. The reason is the easiness of employment without higher and professional education in town; moreover, the social infrastructure in towns is better developed.

In the year 2017, 125011 people arrived in the Krasnoyarsk Territory, and 124082 people preferred to move away. The total migration gain constituted 929 people (4 828 people in 2016). The international migration gain in 2017 (5 394 people) was provided by the CIS countries, with the positive migration balance of 4757 people (according to the Federal State Statistics Service).

Each ethnocultural group is willing to preserve its identity. For this reason, the problem of ethnic self-identification is extremely up-todate due to the possible manifestation of ethnic self-consciousness in the communicative space of various ethnocultures.

One of the most prominent ethnocultural groups resident in the Krasnoyarsk Territory (Krai) is Armenian, having a rich and original national culture. According to the All-Russian Census of 2010, there were 10677 representatives of Armenian ethnic group in Krasnoyarsk. The majority of Armenians live in the urban area (86.7 \%), mostly in the city of Krasnoyarsk (6.1 thousand people). Armenian cultural society Ekhpayrutiun ("Fraternity") has been working in Krasnoyarsk since 1998; since 2000, Armenia

Table 1. Migration gain of the Krasnoyarsk Territory (Krai) as a result of international migration (Federal State Statistics Service)

\begin{tabular}{|l|c|c|c|c|c|c|c|c|c|}
\hline & 2005 & 2006 & 2007 & 2008 & 2009 & 2010 & 2015 & 2016 & 2017 \\
\hline Azerbaijan & -29 & -10 & 573 & 929 & 1054 & 920 & 637 & 694 & 673 \\
\hline Armenia & 37 & 188 & 764 & 905 & 949 & 521 & 516 & 570 & 17 \\
\hline Kazakhstan & 774 & 512 & 542 & 608 & 628 & 477 & 713 & 673 & 395 \\
\hline Kyrgyzstan & 375 & 507 & 1482 & 1558 & 1377 & 1111 & 537 & 946 & 673 \\
\hline Tajikistan & 36 & 125 & 761 & 935 & 1449 & 1290 & 1172 & 1652 & 2118 \\
\hline Uzbekistan & 212 & 254 & 481 & 392 & 461 & 404 & 248 & 217 & 13 \\
\hline Ukraine & -45 & -22 & 621 & 350 & 476 & 359 & 2610 & 1303 & 341 \\
\hline
\end{tabular}


folk dance ensemble started its activity. In 2002, Saint Sarkis (Surb Sarkis) Church was opened, and in 2017, Mesrop Mashtots Armenian Sunday School was established.

Armenian ethnocultural group has proven to be one of the most progressive ones from the point of view of self-promotion in social networks and development of its own information platform. This initiative of attracting public is caused by the wish of the Armenians to involve people into their culture, by their interest in interethnic communication, exchange of traditions, customs, and values. Researchers from Siberian Federal University have conducted a focus group session in order to reveal the peculiarities of ethnic selfmanifestation of Armenian culture in the Krasnoyarsk Territory (Krai). As suggested, the information platform question caused an active reply. The main reason of the information initiatives of the Armenians is explained by the following quotation: "We are Armenians and we want people to know us. We want you to know who your neighbours are and what our thousandyear culture is like. Moreover, the research allows for the conclusion that the traditions the young Armenians follow today mostly concern the relationships between the sexes. It means that manifestation of Armenian identity is translated through traditional behaviour determined by the ethnic culture. These traditions are consistently preserved and maintained. As for other everyday traditions, they have been democratizing, getting adjusted to the current cultural situation. The research demonstrated that ethnic manifestation of Armenians exists in the following forms: 1) Internet communities; 2) public events; 3 ) social organizations. To support ethnic identity of Armenians in the infosphere, the following tools are used: targeting, hashtags, mass texting, reposts from different news communities, music, photo and video footage.

\section{Preparation and execution}

of a focus group session

The Culturology Department of Siberian Federal University has carried out a number of round tables with representatives of the largest ethnic diasporas of the Krasnoyarsk Territory (Krai), i.e. Armenians and Azerbaijanis.

Preparation and execution of a focus group session included all the standard components: research program development; sample selection, member recruitment; 3) focus group method (scenario) preparation, topic guide (question list) formulation; 4) preparation for the focus group session; 5) focus group execution with minutes keeping; 6) qualitative processing and interpretation of data; 7) report preparation.

The moderator and the experts made up a list of questions to be asked to the participants.

\section{Topic 1. Family.}

1) What do you think an ideal family could be like?

2) What are the life plans of your family? Which of them are of greatest importance? Which ones should be achieved in the nearest future?

3) How are the "family chores" distributed in your family? Drawing parallels, does your family resemble a monarchy, democracy or a republic?

4) What is your method of solving conflict situations in your family? What kind of conflict situations is the most frequent?

\section{Topic 2. Education.}

1) Does the higher education existing in modern Russia satisfy the needs of your ethnic group? Does the place of getting higher education matter? Do you think it influences the further life of children?

2) How would you recommend to bring up children to prevent possible ethnic conflicts in the future?

3) What disciplines would you recommend to be included into a school or college curriculum? How would you like your children to be educated? 
4) Do you think the current education reforms will make inclusion of foreign students into Russian reality more comfortable? What advantages you see in the SFU education system?

\section{Topic 3. Employment.}

1) Do you face any employment difficulties?

2) What kind of difficulties are they?

3) Are you satisfied with your job? What makes this kind of activity interesting for you, or is it merely a way of making money?

\section{Topic 4. Cultural traditions.}

1) Do you manage to follow your cultural traditions here, in Siberia? For example, do you celebrate your traditional national holidays?

2) Do your children know the traditions of your culture (songs, fairy tales, celebration rituals etc.)?

\section{Topic 5. Interethnic relations.}

1) What is your attitude to interethnic marriages? (Would you allow your children get married to a person of a different ethnicity?)

2) Do you consider Krasnoyarsk to be your $100 \%$ home, or do you crave to return to your historical ethnic centre?

3) Are there any representatives of other ethnicities among your friends, or do you prefer to keep within your ethnic community (do you communicate with the people of the same ethnos only)?

4) Have you ever faced any conflict situations caused by your ethnic origin?

Topic 6. Language.

1) Do you have any problems with your native language or the official language?

2) Do you think it is necessary to establish separate schools for the children of certain ethnicities? Do you think that children need it, or it is useful for their development, breeding and education (introduction of Khakass language at schools)?

3) What are your prospects in the Krasnoyarsk Territory (Krai)?
Standardly, a focus group consists of 6-10 people. Round tables at SFU gathered from 7 to 10 people. This number is perfect for moderation of the discussion: it maximizes the positive effect of the discussion, prevents long monologues, deviations from the subject, discussion fade outs etc.

The participants were selected with an emphasis made on the representativeness: among the invited, there were men and women from different social groups (from simple workers to high officials), with respect to all other characteristics, such as age, gender, religion, language (it was compulsory for the round table to involve religious people speaking their mother tongue). The key principles of participants selection, homogeneity and diversity, have been observed in this case. Homogeneity means that the focus groups were formed of certain population groups in compliance with the research objective. Diversity means that the participants were selected randomly from the population groups, for all points of view to be represented.

The participants were recruited through Internet sources (invitation sent by e-mail), invited over the phone or through personal contacts. The most popular recruiting method, the "snow ball", was also used: interview respondents with certain features were found among "friends of friends", with the only requirement: the moderator and his/ her assistants must not be familiar with the focus group participants).

The list of suggested and preferred representatives of the ethnic groups was distributed between the authorized professors and post-graduates of the Culturology Department. The main task for each of them was to make up a perfect group of migrants, different from each other in one certain characteristic (social status, gender, age), but identifying themselves as belonging to a certain ethnos (even if they have lived in the territory of Krasnoyarsk over 5-10- 
15 years). The invitations were sent to people open for an intercultural dialogue.

People familiar with the focus group method (having experience of a focused group interview), the moderator, professionally familiar with the subject of the discussion, or colleagues were not allowed to participate.

For the respondents invited to the focus group sessions, the topic of cultural memory for each ethnic group of migrants and its influence on the processes of adaptation, integration and self-identification in the host community was common. The focus groups of the representatives of ethnic cultures had to be homogenous in the social, cultural and ethnically relevant characteristics. It makes a great impact on the authenticity of the results; for this reason, this requirement makes sense both from the scientific, and the ethical points of view. Differences in the aforesaid characteristics make the participants avoid answering the questions, produce spontaneous negative statements, or create an uncomfortable atmosphere at the session.

The focus group sessions were moderated by researchers from Siberian Federal University.

The moderators chosen had to possess the following qualities:

- experience in moderating group sessions;

- ability to establish contacts, express empathy for other people;

- ability to encourage spontaneous conversation;

- good memory (to memorize the topic guide questions and the answers given by the participants);

- empathic listening skill;

- skill of thinking and listening at the same time;

- ability to keep neutral to the focus group participants, to guide the conversation, to return to the topic if necessary;
- trustworthiness, ability to create an easy and friendly atmosphere;

- sense of time for proper organization of the discussion;

- knowledge of group dynamics.

The moderator is also in charge of the development of the topic guide or the focus group session plan. According to the previously developed strategy, the moderator organizes the work in the following order:

a) welcome speech;

b) explanation of the objectives and tasks of the session;

c) introduction of the participants to each other;

d) neutral, easy to answer ice-breaking questions;

e) discussion, problem setting;

f) possible options of problem solving;

g) summary of the session.

The communication within the group is based on the following methods and techniques: quotation of the aforesaid, "naïve questions" method, direct questions, "why" questions etc. The moderator actively uses the "five second pauses" and "requests to clarify" (pause after hearing a statement to encourage expression of opinions or justification of the idea); "request to specify": the moderator may ask a participant to specify the answer, e.g. "Could you tell us more about it?", "Please explain what you mean". As a rule, such requests are used at the beginning of the session to demonstrate the relevance of precise answers. By the end of the session, the questions are more closed (structured) to keep the participants more concentrated on the discussed problems.

Specificity of a focus group session is forming the discussion not only on the basis of direct questions, but around certain topics. The main task of the moderator is to control the conversation, set the problem of the situation, to guide the conversation to a more constructive 
direction. The most important function of the moderator is to talk over the main topic within limited time, making sure the people express their opinions freely, feel friendly and easy. The conversation is conducted in an understandable colloquial language. The communication is built on the two-level principle (a wide topic divided into more specific questions); the dialogue remains flexible (in the process of discussion, the initially planned logic may be broken to a certain extent, but the session plan is not strict or incendiary; it reminds the participants to return to the discussion topic).

Strategy of the discussion is a gradual transition from a wider topic to narrower issues: the questions get more specific, the respondents are encouraged to give straight answers, as the less versions of answers are provided by the participance, the more profound is the collected information (the more theories are considered at the public discussion, the less time can be allocated to each).

The target audience consists of scientists, professors, representatives of ethnic migrant groups, post-graduate students and doctoral candidates, students, culture managers.

\section{Results of the research of ethnocultural groups resident in the Krasnoyarsk Territory (Krai) with the focus group method}

As a result of the group discussion sessions organized and carried out with the ethnocultural groups of the Krasnoyarsk Territory (Krai) (Azerbaijanis and Armenians), intended to reveal the attitude of the ethnic groups to the problems of their history, motherland, family, ethnicity, interethnic relations, assimilation, integration, ethnic self-identification, we may formulate the following:

History and motherland. Representatives of each ethnic group who have not lost their identification with the ethnos and strive to preserve it, wish to leave for their historical motherland.

The participants explained, that the ethnic Armenians "came to Siberian construction sites in the 1990-s, as well as in the USSR era to study at Krasnoyarsk colleges and to hide from interethnic conflicts. They started families, got employed, and decided to stay "for a while". The younger generation is interested in going either to their parents' motherland where their grandparents and other relatives live, or "to the West", for example, to the USA, the home of one of the greatest Armenian diasporas in the world, or to Australia, which also has its Armenian community.

The focus group participants said that Armenians have a strong sense of ethnic brotherhood, respect for tribal feelings, hospitality, and dignity. Special attitude to faith was also remarked: Armenian Christian church is "the oldest in the world; Armenians adopted Christianity as soon as they heard about right, immediately after the resurrection of Christ". Armenian believers go only to the Armenian church maintained by the Armenian diaspora.

For Armenian ethnocultural group, motherland is the place where Armenians were born, the place where all of them long to return (including those born in the Krasnoyarsk Territory). They think of their motherland with sincere love (this is their "promised land"), even though many Armenians still prefer to go working abroad.

Moreover, each ethnocultural group understands its motherland as the centre of the world, the historically primary land, important not only for Russia, but for the entire world.

Those ready to stay in Russia, in the Krasnoyarsk Territory, are the ones who have already assimilated, i.e. the young generation born in the Krasnoyarsk Territory and having 
friends among the locals. An Azerbaijani participant of the session said the following: "Of course, I think of Krasnoyarsk as of my home town, because I was born here, and lived here through my childhood, which is 18 years of my life. Home is the place where you feel good, and I am really good here. I like everything here".

Azerbaijanis do not forget their ethnic language and culture; the families still speak their mother tongue. Azerbaijani participants of the focus group session said they wished their motherland to live in peace, so that they could return there.

Moreover, the focus group participants remark the prestige of belonging to their ethnos. They mentioned such positive qualities of their nation as high moral standards, academic success of the children ("they are praised by teachers"), choice of prestigious professions, respect for their seniors etc.

The majority of the focus group participants accept interethnic marriages; however, they prefer monoethnic families. Those are seniors who advocate monoethnic marriage when choosing wives for their sons, developing the image of perfect family in the minds of the youth. For Armenian participants, family is the greatest value, the beginning of the beginnings, the greatest support. It is not the nationality of the partner, but the life principles and moral standards that matter.

For Azerbaijani respondents, a perfect family it is not a matter of ethnicity; the most important things are mutual respect and understanding between the partners. Parents still play an important role in choosing a wife for their son. In their children, parents nurture respect for all people, regardless of their ethnicity; interethnic hatred is never encouraged. Girls mostly prefer to get married to Azerbaijanis, while men can choose a bride from any ethnic group. It is noticed that marriages in this ethnocultural group are usually long lasting, with the divorce rate not exceeding 3 per cent.

Generally, family is the origin, the institution that develops the basic values regardless of its territorial location: in the historical motherland or in the territory of current residence (the majority of respondents speak their mother tongue at home to teach the language to their children).

Common nationalism problems. Azerbaijani focus group participants remarked, that the least tolerant people are residents of Moscow and Saint Petersburg; the same problem exists in Krasnoyarsk, and migrant phobia and xenophobia are directly connected to the wealth of the population: the less the income, the more complicated their interethnic relations are.

It has been noticed that tolerance for other ethnic groups is predominantly found in the circle of intelligentsia and senior citizens (brought up in the Soviet Union). Correspondingly, the lower the social status, the less tolerant the group is.

Young generation identifies its belonging to the ethnic group among the peers (e.g., at the themed social organizations, cultural associations, in other countries).

\section{Conclusion}

The use of the qualitative focus group method to ethnocultural process studies helps to detect a certain ethnic identity of the senior generation, developed in a specific cultural environment: belonging to a certain ethnos, self-identification with the representatives of this ethnos and its culture (traditions, values, regulations, memory), separation from other ethnicities. Identifying itself with its ethnic group, one actualizes the cultural memory existing in the ethnic culture. Ethnic identity is achieved on the basis of a certain world outlook and a model of attitude to the world, both external and internal factors, determinant for its existence. Young generation 
of migrants prefer to identify themselves as belonging to Russian culture. Social heritage of the youth is different from the ethnic one: though some ethnic assimilation takes place (language, everyday communication culture in a foreign environment), ethnocultural consolidation is yet out of question.

Focus group is a promising and productive method of collecting sociological and cultural information from representatives of certain ethnic cultures. The methodological base of applying qualitative research methods to the studies of migration processes and interethnic relations, and focus group method in particular, is a positive synthesis of certain theories (ethnomethodological and phenomenological theories, interpretative sociology, symbolic interactionism), and age, ethnicity, culture, socio-psychological characteristics of the people belonging to various ethnocultural groups.

Such methodological base directs the process of studying an ethnos from the everyday life world of every certain representative of this or that ethnic culture to the construction of the social and cultural environment of the ethnos as a whole and in the context of interethnic relations.
Such researches present a way of profound interpretation and analysis of interethnic relations, self-identification, integration and adaptation of ethnocultural group, provides an opportunity for their representatives to speak their mind and be heard, makes them understand that their opinion matters and it is the purpose of the session, and that the problem cannot be solved without them. In a dialogue of cultures, focus groups act as a guarantor of a complete, mutually necessary contact of parties and cooperation. This kind of research activity illustrates the current humanitarian trend in modern social development.

Moreover, a significant advantage of any group discussion and focus group method in particular is the opportunity of tracing the individual behaviour model in the context of a group. Being one of the key components in group discussions, the group dynamics phenomenon manifests itself in the small group context.

Experience of working the group dynamics and competence in the small group functioning issues are the compulsory conditions of a successful empiric research based on various group interview methods.

\section{References}

Belanovskiy, S.A. (1996). Metod fokus-grupp [Focus Group Method]. Moscow: Magistr Publishing House, 272.

Briantseva, E.A. (2005). Metod fokus-gruppy kak instrument analiza potrebitel'skoy sotsializatsii v sovremennoy Rossii [The Focus Group Method as a Tool for Analyzing Consumer Socialization in Modern Russia], In: Budushchee Rossii: strategii razvitiia. Materialy mezhd. nauchn. konf. «Lomonosov-2005». Sb. statey molodykh uchionykh [The Future of Russia: Development Strategies. Proceedings of the International Scientific Conference "Lomonosov 2005". Collection of Articles by Young Researchers]. Moscow: Maks press.

Briantseva, E.A. Osobennosti formirovaniia $\mathrm{i}$ primeneniia metoda fokus-gruppy $\mathrm{v}$ sotsiologicheskom issledovanii [Peculiarities of the Formation and Application of the Focus Group Method in a Sociological Study], In: E-Library of the Sociology Department of Lomonosov Moscow State University. Available at: http://lib.socio.msu.ru/l/library?e=q-000-00---0lomon--00-0-00prompt-10---4------0-11--1-ru-50---20-about-\%f4\%ee\%ea\%f3\%f1--00031-001-1-0windowsZz-1251$00 \& \mathrm{a}=\mathrm{d} \& \mathrm{c}=$ lomon $\& \mathrm{cl}=\mathrm{search} \& \mathrm{~d}=\mathrm{HASH} 3 \mathrm{~d} 10941 \mathrm{bdc} 94 \mathrm{efd} 0 \mathrm{acf} 613.2$. 
Briantseva, E.A. (2011). Fokus-gruppy v sotsiologicheskom issledovanii tsennostey materey novorozhdennykh detey v usloviiakh meditsinskogo uchrezhdeniia [Focus Groups in Sociological Research of Values of Mothers of Newborns in the Medical Institution Environment], In: Perspektivnye razrabotki nauki i tekhniki. Sb. st. VII mezhdunarodnoy nauchno-praktich. konf. Psikhologiia $i$ sotsiologiia [Psychology and Sociology], 31, 86-90.

Chekhovskiy, I.V. Metodologiia sotsiologicheskikh issledovaniy [Methodology of Sociological Research], In: Metod fokus-grupp v kontekste gruppovyx intervyu [Focus Group Method in the Context of Group Interviews]. Available at: http://ethnography.omskreg.ru/page.php?id=814.

Dmitireva, E.V. (1999). Metod fokus-grupp: problemy podgotovki, provedeniia, analiza [Focus Groups Method: Problems of Preparation, Execution, Analysis], In: Sotsiologicheskie issledovaniia [Sociological Research], 8, 133-138.

Folomeeva, T.V. (2003). Ispol'zovanie proektivnykh metodik dlia povysheniia effektivnosti fokusgrupp [Application of Projection Techniques for Increasing Focus Group Efficiency], In: Sotsiologiia: metodologiia, metody, matematicheskoe modelirovanie (4m) [Sociology: Methodology, Methods, Mathematic Modeling (4M)], 17, 83-108.

Institut arkheologii i etnografii sibirskogo otdeleniia rossiyskoy akademii nauk: internet-zhurnal Sibirskiy Etnograficheskiy Vestnik. [Archaeology and Ethnography Institute of the Siberian Branch of the Russian Academy of Sciences: Internet Journal Siberian Ethnographic Newsletter]. Available at: http://www.sati.archaeology.nsc.ru/sibirica.

Kafedra etnografii i muzeevedeniia Omskogo gosudarstvennogo universiteta [Department of Ethnography and Museum Studies, Omsk State University]. Available at: http://ethnography.omskreg. ru/page.

Krueger, R. (1988). Fokus-gruppy [Focus Groups], In: Prakticheskoe rukovodstvo dlia prikladnykh issledovaniy [Practical Guide for Applied Research], 61 p.

Moskovskiy tsentr gendernykh issledovaniy. Fokus-gruppa: izuchenie gendernoy identichnosti [Gender Research Centre of Moscow. Focus Group: Gender Identity Study]. Available at: http://www. gender.ru/pages/resources/catalogue/index.php?prgid=18\&id=2\&subid=2.

Robber, M.A. (1995). Gruppovoe interv'iu [Group Interview], In: Khrestomatiia po sotsialnoy psikhologii [Anthology of Social Psychology]. Moscow, 189-193.

Shchedrina, O.V. Vozmozhna li mul'tikul'turnaia model integratsii migrantov v Rossii? [Is a Multicultural Model of Migrants Integration Possible in Russia?], In: Sotsiologicheskie issledovaniia [Sociological Research]. Available at: http://demoscope.ru/weekly/2006/0231/analit02.php.

Sibirskiy filial Rossiyskogo instituta kulturologii [Siberian Branch of the Russian Institute of Cultural Studies]. Available at: http://sfrik.omskreg.ru.

Tomilov, N.A. Itogi i perspektivy etnograficheskogo izucheniia narodov Sibiri i Dal'nego Vostoka [Results and Prospects of Ethnographic Study of the Peoples of Siberia and the Far East]. Available at: http://www.sati.archaeology.nsc.ru/sibirica/Data/?html=013.htm\&mi=25\&id=659.

Tomilov, N.A. (2001). Mezhdunarodnyy nauchnyy seminar "Integratsiia arkheologicheskikh i etnograficheskikh issledovaniy" i ego vklad v razvitie rossiyskoy etnoarkheologii [International Scientific Seminar "Integration of Archaeological and Ethnographic Research" and Its Contribution to the Development of Russian Ethnoarchaeology], In: Istoriia i kul'tura Sibiri [History and Culture of Siberia]. Omsk, 91-119. 
Tomilov, N.A. (2001). Narody i natsional'nye gruppy Zapadnoy Sibiri v 60-90-e gody XX v. i reshenie natsionalnykh problem [Peoples and Ethnic Groups of Western Siberia in the 1960-90-s. and Ethnic Problems Solutions], In: Etnosotsialnye protsessy v Sibiri [Ethnosocial Processes in Siberia]. Novosibirsk, 4, 42-45.

Tomilov, N.A. Podgotovka kadrov etnografov v oblasti izucheniia kul'tury narodov Sibiri [Training Ethnographers in the Field of Culture Studies of Siberian Peoples], In: Narodnaia kul'tura Sibiri: nauchnye poiski molodykh issledovateley [Popular Culture of Siberia: Scientific Works by Young Researchers]. Omsk, 19-25.

Tomilov, N.A. (2000). Etnograficheskoe i etnosotsiologicheskoe izuchenie vostochnykh slavian zapadnoy Sibiri v posledney chetverti XX veka [Ethnographic and Ethnosociological Studies of the Eastern Slavs of Western Siberia in the Last Quarter of the Twentieth Century], In: Gumanitarnye nauki $v$ Sibiri [Humanities in Siberia]. Novosibirsk, 3, 48-51.

Tomilov, N.A. (2000). Etnichnost', etnicheskie obshchnosti i protsessy (v sviazi s rabotami Vladimira Fiodorovicha Geninga) [Ethnicity, Ethnic Communities and Processes (in Connection with the Work of Vladimir Fedorovich Gening)], In: Rossiyskaia arkheologiia: dostizheniia XX i perspektivy $X X I v v$. [Russian Archeology: Achievements of the $20^{\text {th }}$ and the Prospects of the $21^{\text {st }}$ Century]. Izhevsk, $15-18$.

Viacheslav Igrunov website. Round Table Proceedings. Available at: http://igrunov.ru/prj.

\section{Культурная память мигрантов Красноярского края и процессы этнической самоидентификации}

Ю.Н. Авдеева

Сибирский федеральный университет

Россия, 660041, Красноярск, пр. Свободный, 79

Предметом исследования является культурная память мигрантов Красноярского края. Трудовая миграчия в Красноярском крае - это сочиальный, экономический и культурный процессы. Мигранты составляют значительную долю населения Красноярского края. Процессы этнической идентичности мигрантов служат актуальным предметом культурных исследований. Этническая идентификация мигрантов Красноярского края обусловлена их культурной памятью. Содержание культурной памяти важно для понимания процессов, связанных с государственной культурной и миграционной политикой. Трудовая миграция оказывает существенное воздействие на социальное и культурное пространство региона.

Основной метод исследования - фокус-группа. Этот метод был применен к мигрантам Красноярского края, принадлежащим к армянской, азербайджанской и другим этническим культурным группам.

Научная новизна исследования связана с применением метода фокус-группы для выявления содержания культурной памяти мигрантов Красноярского края. Молодое поколение мигрантов отождествляет себя с российской культурой. Социальное наследование молодежи отличается от их этнического наследования: происходит этническая ассимиляция (язык, культура повседневного общения в иноэтничном пространстве), но об этнокультурной консолидации говорить пока не приходится. 
Ключевые слова: культурная память, этничность, этническая идентичность, этническая самоидентификачия, этнокультурные группы, этнос, миграџия, миграџионные процессы, миграиионная политика, фокус-группь, культурные исследования.

Научная специальность: 24.00.00 - культурология. 